\title{
NUMERICAL SIMULATION OF FLOODING IN JAKARTA AND EVALUATION OF A COUNTER MEASURE TO MITIGATE FLOOD DAMAGE
}

\author{
Idham Riyando MOE${ }^{1}$, Shuichi KURE², Mohammad FARID ${ }^{3}$, Keiko UDO4, \\ So KAZAMA ${ }^{5}$ and Shunichi KOSHIMURA ${ }^{6}$ \\ ${ }^{1}$ Member of JSCE, Department of Civil and Environmental Engineering, Tohoku University \\ (Aoba 468-1 Aoba-ku Sendai-shi Miyagi, 980-0845, Japan) \\ E-mail:idham.moe@gmail.com \\ ${ }^{2}$ Member of JSCE, Assistant Professor, International Research Institute of Disaster Science, Tohoku University \\ (Aoba 468-1 Aoba-ku Sendai-shi Miyagi, 980-0845, Japan) \\ 3 Researcher, Water Resources Engineering Research Group, \\ Faculty of Civil and Environmental Engineering, Bandung Institute of Technology \\ (Jalan Ganesha 10 Bandung 40132, Indonesia) \\ ${ }^{4}$ Member of JSCE, Associate Professor, International Research Institute of Disaster Science, Tohoku University \\ (Aoba 468-1 Aoba-ku Sendai-shi Miyagi, 980-0845, Japan) \\ ${ }^{5}$ Member of JSCE, Professor, Department of Civil and Environmental Engineering, Tohoku University \\ (Aoba 6-6-06 Aoba-ku Sendai-shi Miyagi, 980-8579, Japan) \\ ${ }^{6}$ Member of JSCE, Professor, International Research Institute of Disaster Science, Tohoku University \\ (Aoba 468-1 Aoba-ku Sendai-shi Miyagi, 980-0845, Japan)
}

\begin{abstract}
Floods in Indonesia are considered to be one of the major natural disasters. Jakarta City in Indonesia has experienced many floods in the past, such as those in 1996, 2002, 2007 and 2013. In this paper several problems causing the floods in Jakarta were discussed and a flood inundation model was applied to the 2007 and 2013 flood events. Also, a counter measure to increase the flood flow carrying capacity of the Ciliwung River was evaluated by a numerical simulation. As a result of analysis, it was found that the applied flood inundation model relatively well reproduced the flood inundation situation in Jakarta. Further, the counter measure that increased the flood flow capacity of the target sections by $150 \%$ was found to reduce the flood inundation volume by nearly $15 \%$. However, considering the fact that there are still many areas remaining inundated, it would also be needed to investigate the effects of other rivers and several other factors contributing to flooding in Jakarta.
\end{abstract}

Key Words: Jakarta, urban flooding, flood inundation model, flood flow capacity

\section{INTRODUCTION}

Floods are one of the natural hazards with a great impact to human activities and its frequency has been increasing during the last few years. Floods in Indonesia are considered to be one of the major natural disasters. Jakarta City in Indonesia has experienced many floods in the past, such as those in 1996, 2002, 2007, 2013 and 2014 (Table 1). The flood in February 2007 resulted in more than 80 deaths, and $40 \%$ of the area in Jakarta was inundated. Also, electrical system shutdowns in several districts in the city were reported. The flood event in 2013 caused the similar situation, which resulted in more than 40 deaths, 45,000 refugees, and terrible economic damage. Extreme flooding events might become more frequent in the future due to the impacts of land use change (urbanization) in the upstream region (e.g. Farid et al. ${ }^{1)}$ ) and the climate change (e.g. Kure and Tebakari ${ }^{2)}$ ).

There are many factors contributing to the floods in
Jakarta. According to Bricker et al. ${ }^{3)}$, the reduced capacity of the drainage system by trash clogging flood gates was raised as one factor for the flooding. Kure et al. ${ }^{4)}$ emphasized that the shortage of capacity flow in the lower Ciliwung River is one of the factors for the flooding in the lower sections of Jakarta. Farid et al. ${ }^{1)}$ pointed out that the urbanization of the Ciliwung River basin is contributing to increase of the flood flow in the river, and the land use change impacts on the runoff in Ciliwung River basin were evaluated by a numerical simulation.

The intended plan by the Ministry of Public Works, Indonesia through Directorate General of Water Resources, River Basin Organization of CiliwungCisadane to drain the water out of the city was by constructing a floodway in the shape of a horseshoe surrounding Jakarta. Therefore, the West Canal (Banjir kanal Barat) was constructed and still functions today. However, the construction of the East Canal (Banjir Kanal Timur) delayed and just recently finished because 
Table 1 Summary of the recent flood events.

\begin{tabular}{|c||cccc|}
\hline \multicolumn{1}{|c||}{} & $\begin{array}{c}\text { Total Rainfall } \\
\text { (72-hour) } \\
\mathrm{mm}\end{array}$ & $\begin{array}{c}\text { Maximum WL at } \\
\text { Manggarai } \\
\mathrm{m}\end{array}$ & $\begin{array}{c}\text { Death } \\
\text { Toll } \\
\text { person }\end{array}$ & Main damage \\
\hline \hline 1996 & 311 & 9.7 & 10 & ?? \\
2002 & 235 & 10.5 & 32 & Elecrical System Shutdown \\
2007 & 467 & 10.6 & 80 & Elecrical System Shutdown \\
2013 & 222 & 10.2 & 41 & Embankment failure \\
2014 & 259 & 9.7 & 26 & $? ?$ \\
\hline
\end{tabular}

Rainfall: Katulampa subbasin (upper) average

its project faced a financial problem several years ago. As such, some counter measures to reduce flood damages in Jakarta have been proposed and implemented. However, the mechanism of flooding in Jakarta has not been clarified yet, and quantitative evaluations of the proposed counter measures have not been conducted because of the complex flooding mechanism in Jakarta.

The main objective of this paper is to develop a flood inundation model that covers not only the Ciliwung river basin but also Jakarta City and to evaluate several counter measures for reducing the extent of flood damage and developing effective flood counter measures.

\section{STUDY AREA AND DATA USED}

Jakarta, officially known as the Special Capital Region of Jakarta, is the capital and largest city of Indonesia with a population of about 9.6 millions. The Central Jakarta is the seat of national government as well as seat of the provincial government of Greater Jakarta. This city is moreover the country's center of finance and business.

Thirteen major rivers flow northwards through Jakarta into the Java Sea. The main river in Jakarta is the Ciliwung River with the upstream area in Pangrango Mountain and the downstream area in Jakarta. The Ciliwung River is the longest river which passes through Jakarta and some areas in West Java Province, as shown in Figure 1. The Ciliwung River has a catchment area of $382.6 \mathrm{~km}^{2}$ with the river length of 117 $\mathrm{km}$. The influence of the Ciliwung River on the Jakarta region is the biggest among other rivers flowing into Jakarta. It can be said that the occurrence of floods in Jakarta is always related to the Ciliwung River, especially in the upper part of the river.

The target area selected in this study includes Jakarta and the Ciliwung River basin totally covering $1346.6 \mathrm{~km}^{2}$ as shown in Figure 1. The Digital elevation model (DEM) from Shuttle Radar Topography Mission (SRTM) with resolution 90 meters was employed in this study. For the soil data, the dataset from the Food and Agriculture Organization of the United Nations (FAO) was employed for the determination of model parameters used in this study. The data of cross sections of rivers and the drainage system were obtained from the project authority of JICA on the Ciliwung River in 2011. Rainfall data in the target area was provided by the BMKG (Badan Meteorologi, Klimatologi dan Geofisika: Indonesian Agency for Meteorology, Climatology and Geophysics), and water level data of the Ciliwung River and flood inundation map of Jakarta were provided by the BPBD (Badan Penanganan Bencana Daerah: Jakarta Disaster Management Agency).

\section{PROBLEMS CAUSING FLOODS IN JAKARTA}

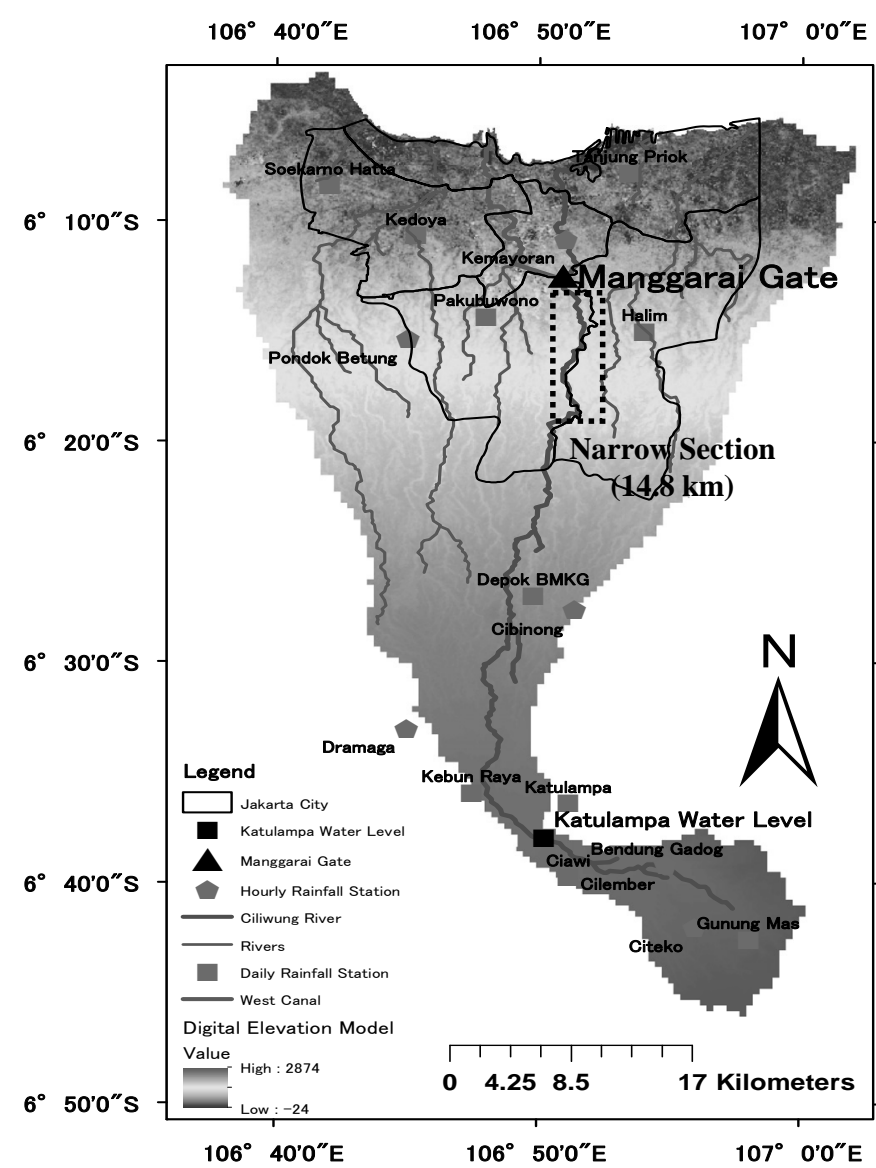

Fig. 1 Study area and the location of the observation stations. 
Heavy rainfall in and around Jakarta due to the tropical monsoon may have been a main factor contributing to the 2013 flood (Kure et al. ${ }^{4}$ ). However, not only heavy rainfall but also several problems causing floods in Jakarta were reported.

A rapid urbanization of Jakarta due to economic growth accompanied by its rapid population expansion is contributing to the increase of the flood risk in Jakarta. According to Farid et al. ${ }^{1)}$, the urbanization of the catchment has caused floods to expand further and faster with the increase of the effective rainfall and surface runoff.

Land subsidence is widely known to be a serious problem causing urban flooding in the lowland areas of Jakarta. According to Atlas ${ }^{5)}$, the land subsidence ranging from $0.1 \mathrm{~m}$ to $4.0 \mathrm{~m}$ occurred in the lowland areas of Jakarta from 1974 to 2010. This land subsidence may be a factor leading to urban flooding in these specific lowland areas. Many parts of the lowland areas are located below mean sea level so these areas are easily inundated by intensive rainfall, and dewatering is difficult due to the need of pumps.

In addition, lack of regular dredging of the city's drainage system is another possible cause of repeated flooding in Jakarta. The problem of sedimentation in Jakarta's canals has been unrecognized, and dredging has once again come to the forefront of the city's priority issues. Also, there is a section with the shortage of capacity flow in the lower part of the Ciliwung River (Figure 1) because of the narrow river cross sections and illegal developments in the floodplain. The area around this section is easily inundated by high flows from the upstream during the flood events.

As mentioned above, many factors have been contributing to flooding in Jakarta, and their effects on the floods should be evaluated quantitatively. In this paper, the effects of the shortage of capacity flow in the lower part of the Ciliwung River on the flood inundation volume are evaluated by a numerical simulation in order to propose a counter measure to increase the flood flow carrying capacity in the section.

\section{MODEL COMPONENTS}

In this study, a physically based rainfall-runoff and flood inundation model was employed in order to understand the flood characteristics in Jakarta City. The model consists of rainfall-runoff module at each subbasin, hydrodynamic module in the river and canal networks, and flood inundation simulation for the floodplains.

\section{(1) Rainfall distribution}

In this study area, it is difficult to find rainfall data with high temporal and spatial resolutions. For the 2013 flood event, only 5 of 17 rain gauges provided hourly rainfall data, as shown in Figure 1. This number is not adequate to provide a good spatial distribution of hourly rainfall for model input. Accordingly, to estimate spatial hourly rainfall distribution, a spatial interpolation method proposed by Farid et al. ${ }^{1)}$ was employed in this study. Basically, the method is based on simple linear interpolation, and the value of hourly rainfall data at a station is estimated by using such data of two nearest stations with the hourly rainfall deviation from daily average taken into consideration. For the details, see Farid et al. ${ }^{1)}$.

\section{(2) Rainfall runoff simulation}

For the rainfall runoff simulation, the model proposed by Kure et al. ${ }^{6), 7)}$ was employed. The model is based on the kinematic wave theory for a hillslope, and it computes surface and subsurface flows based on the geological and hydrological characteristics at each subbasin. Model parameters are determined by DEM and soil datasets.

From a subbasin delineation tool in ArcMap (ver.10.1) with DEM data, 40 subbasins with an area ranging from $0.04 \mathrm{~km}^{2}$ to $88.6 \mathrm{~km}^{2}$ were delineated. Slope gradients at individual subbasins in the target area are mostly mild ranging $2-16$ degrees. The soil parameters were obtained from FAO data by means of Kure et al. ${ }^{8)}$. Soil depth for Ao layer was determined with a range of $97 \mathrm{~mm}$ to $215 \mathrm{~mm}$, and the total porosity ranging from 0.45 to 0.5 was obtained.

\section{(3) Flood routing in rivers and drainage sytem}

For the flood routing and inundation, MIKE FLOOD (DHI), integrated system of MIKE 11 and MIKE 21, were employed in this study. A flood routing in rivers and a drainage system were conducted based on the MIKE 11. MIKE 11 simulates a 1D flow with dynamic wave description by solving the vertically integrated equations of conservation of continuity and momentum (the Saint-Venant equations). The Saint-Venant equations for conservation of continuity and momentum are written as follows:

$$
\begin{gathered}
\frac{\partial A}{\partial t}+\frac{\partial Q}{\partial x}=q_{l} \\
\frac{\partial Q}{\partial t}+\frac{\partial\left(\alpha \frac{Q^{2}}{A}\right)}{\partial x}+g A \frac{\partial h}{\partial x}+\frac{g n^{2}|Q| Q}{R^{4 / 3} A}=0
\end{gathered}
$$

where, $Q$ is the discharge, $A$ is the area of cross-section, $q_{l}$ is the lateral inflow or outflow distributed along the $\mathrm{x}$-axis of the watercourse, $n$ is the manning's roughness coefficient, $\alpha$ is the momentum distribution coefficient, $g$ is the acceleration of gravity, $R$ is the hydraulic radius and $h$ is the water level.

The observed base flow values were used for the upstream boundaries and the observed hourly tide data were employed for the lower boundary conditions. The observed base flow values were determined from the observed water level data with a rating curve proposed by the BPBD at the Katulampa station shown in Figure 1. The lateral flow $q_{l}$ in Eq. (1) are simulated by the 
rainfall runoff model explained above.

For the river cross sections, the measured data by JICA project were employed in this study. However, there are no observed data available from upstream rivers and small tributaries. In that case we assumed the river cross sections as having a rectangular shape, and river width data were measured from Google Map views and mean river bed elevations were extracted from DEM. Also, the river depths were assumed by using simple emprical equations proposed by Carpenter et al. ${ }^{9)}$.

\section{(4) Flood inundation simulation}

For the flood inundation, the unsteady twodimensional flow equations consisting of the continuity equation and momentum equation are numerically solved in MIKE 21. The flood routing simulation by MIKE 11 and the flood inundation by MIKE 21 are dynamically integrated through the MIKE FLOOD system. The river (MIKE 11) is linked laterally to floodplain (MIKE 21) to represent spilling from the river to the flood plain and drainage back into the river. For detailed information, see the reference ${ }^{10)}$.

\section{(5) Urban flood simulation}

As described in the previous chapters, Jakarta is a highly urbanized area, and many parts of the area affected by rainfall directly contribute to the urban flooding without the hydrologic processes at the subbasins and the flood routing in the drainage system.

In this paper, we assume that a certain percentage of rainfall directly contributes to urban flooding, and the percentages of rainfall at individual subbasins equal to the urbanization ratios. The urbanization ratios employed in this study were obtained from the global land cover map ${ }^{11)}$ by the European Space Agency. According to this dataset, Jakarta's urbanization ratio is about $73 \%$. Thus, about $73 \%$ of rainfall in Jakarta was set as the input to the two-dimensional unsteady flow simulation through a source term in the equations although about $27 \%$ of rainfall in Jakarta was set as the input to the rainfall runoff simulation at each subbasin in Jakarta. It should be noted that the percentage of rainfall varies depending on the urbanization ratio of subbasin and thus different values are employed for each subbasin.

\section{(6) Model application results}

The model was applied to the Ciliwung River basin for the 2013 flood event of January 14 - 19, 2013. The 2013 event was selected as the calibration event because this event has an observed inundation map in Jakarta. The manning's roughness coefficients of the land surface for flood inundation and the river bed for flood routing in river and the drainage system were calibrated to achieve a good agreement of the simulated and observed inundation areas in Jakarta. The Manning's roughness coefficients of the river sections were

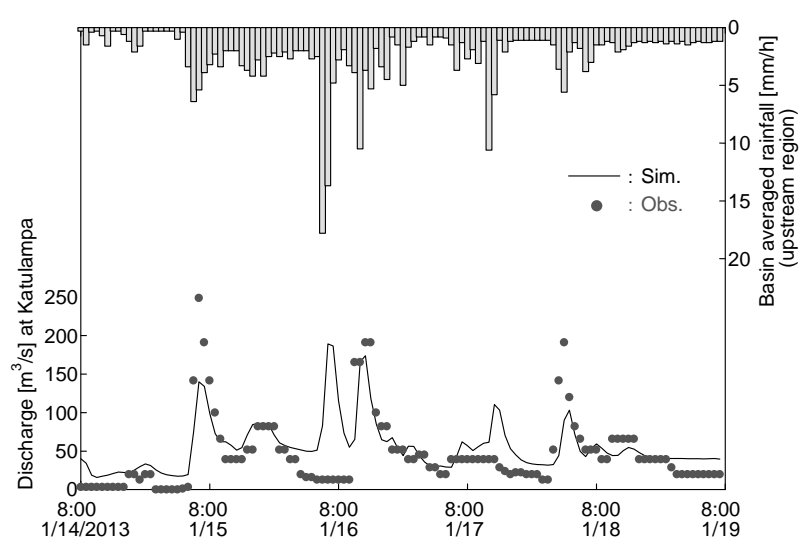

Fig. 2 Comparison of the observed and simulated discharge at Katulampa station.

calibrated by a try and error exercise, comparing the simulated and observed river discharge at the Katulampa point (Figure 1). The comparison between the observed and simulated river discharge at Katulampa after the calibration is shown in Figure 2. It can be seen from this figure that there are discrepancies between the observed and simulated discharge, and their correlation coefficient is 0.60 . In order to get a better agreement, the input data of the rainfall spatial distribution should be improved because there are time discrepancies between the basin averaged rainfall in the upstream region and the observed river discharge in Figure 2. This implies that the rainfall interpolation method used in this paper could not capture the actual rainfall distribution in the target area. The next option to improve the rainfall distribution is to use a radar information data that is available in the target area.

From the calibration, the manning's roughness coefficients of the river beds were set from 0.03 to 0.1 $\mathrm{m}^{-1 / 3} \mathrm{~s}$ for river sections. However, there is no available time series data of the inundation area and/or depth in Jakarta, so that the manning's roughness coefficients of the land surface was calibrated to reproduce the most possible similar inundation extent against the reported inundation zones. From the calibration, the said coefficients of the land surface were set as $0.6 \mathrm{~m}^{-1 / 3} \mathrm{~s}$ for the all floodplains.

Figure 3 shows the observed inundation area in Jakarta and the simulated maximum inundation depth of the target area. The observed flooded area data was provided by the BPBD, and the data was based on the eyewitness reports by government officers during the flood event and interviews with local residents after the event although there are some uncertainties. It is noted that the inundation in the northern coastal area is mainly from urban flooding caused by several problems, such as land subsidence, as discussed in the previous chapter. The simulated inundation area in the target area matched relatively well with the observation results, namely, at the north-east and -west of Jakarta and the upstream area of the Manggarai gate point. 

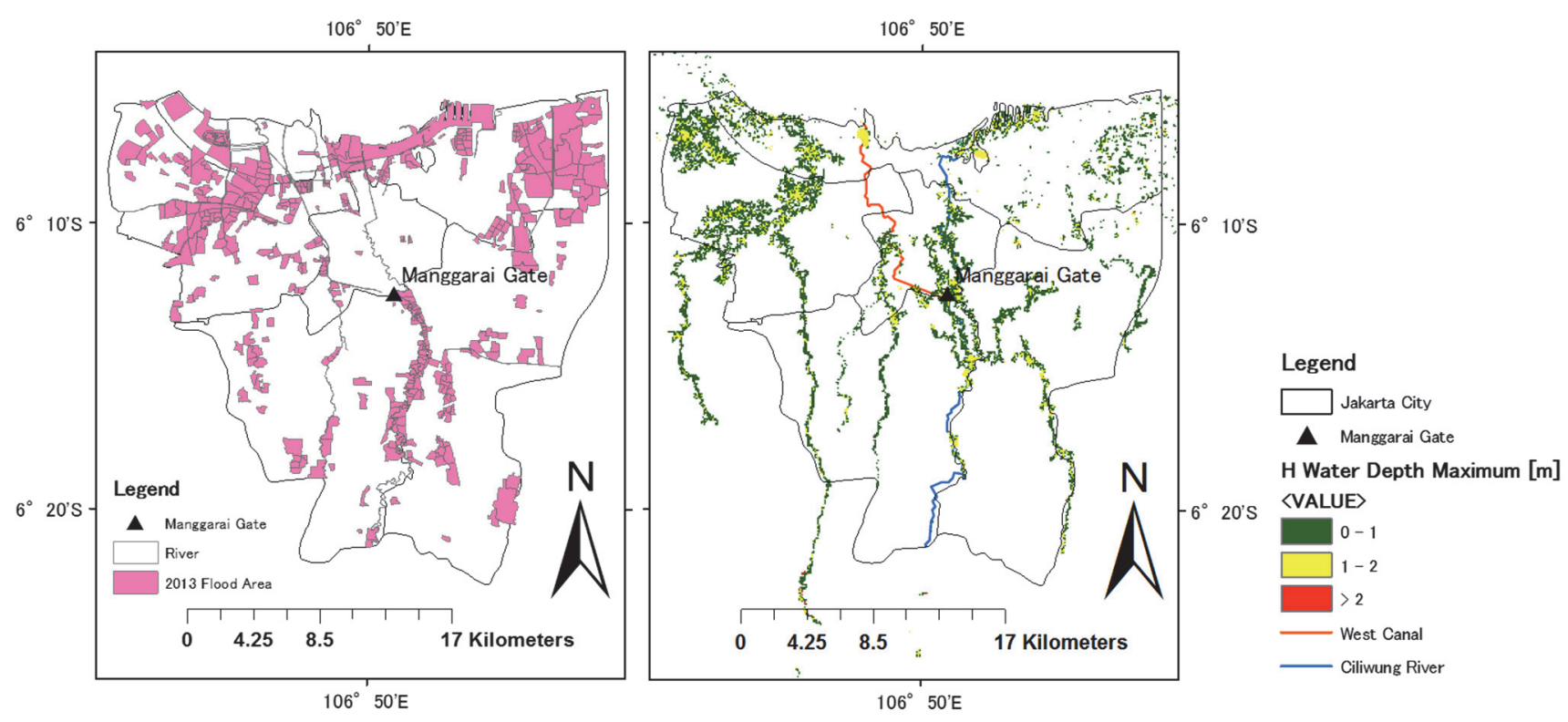

Fig. 3 Comparisons between the observed (left) and simulated (right) inundation areas.
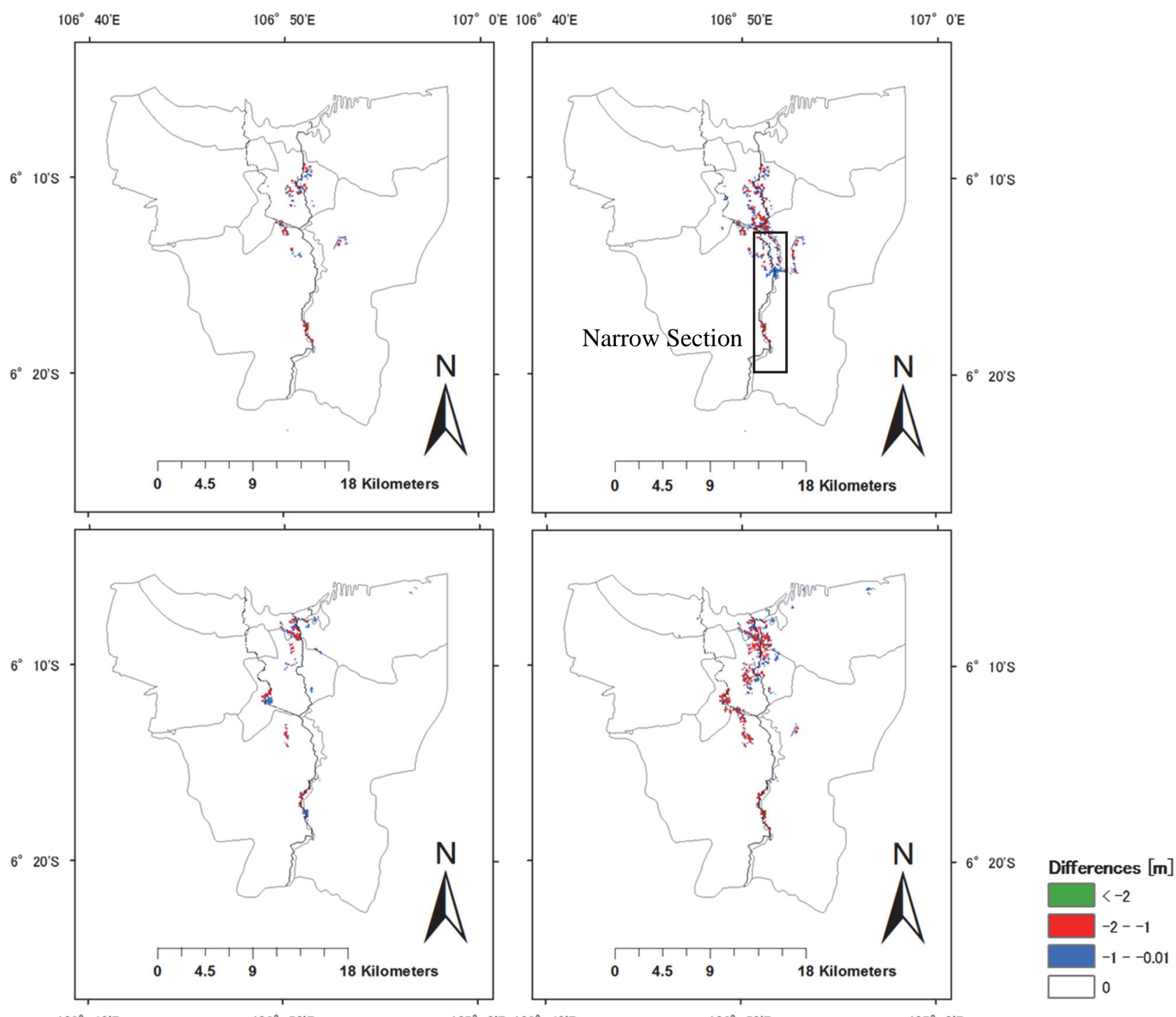

$106^{\circ} 40^{\circ} \mathrm{E} \quad 106^{\circ} 50^{\circ} \mathrm{E} \quad 107^{\circ} 0^{\circ} \mathrm{E} 106^{\circ} 40^{\circ} \mathrm{E}$

$106^{\circ} 50^{\circ} \mathrm{E}$

$107^{\circ} O^{\prime} E$

Fig. 4 Difference of the inundation depth after the implementation of the countermeasure at Case 1 (left) and 3 (right) of the 2013 (upper) and 2007 (lower) events. 
Table 2 Summary of the simulation results at each case of the events.

\begin{tabular}{|c|c|c|c|c|c|c|c|c|}
\hline \multirow{2}{*}{ Year } & Original Simulation & \multicolumn{2}{c|}{ Case 1 } & \multicolumn{2}{c|}{ Case 2 } & \multicolumn{2}{c|}{ Case 3 } \\
\cline { 2 - 9 } & $\begin{array}{c}\text { Area } \\
\left(\mathrm{km}^{2}\right)\end{array}$ & $\begin{array}{c}\text { Volume } \\
\left(\mathrm{m}^{3}\right)\end{array}$ & $\begin{array}{c}\text { Area } \\
\left(\mathrm{km}^{2}\right)\end{array}$ & $\begin{array}{c}\text { Volume } \\
\left(\mathrm{m}^{3}\right)\end{array}$ & $\begin{array}{c}\text { Area } \\
\left(\mathrm{km}^{2}\right)\end{array}$ & $\begin{array}{c}\text { Volume } \\
\left(\mathrm{m}^{3}\right)\end{array}$ & $\begin{array}{c}\text { Area } \\
\left(\mathrm{km}^{2}\right)\end{array}$ & $\begin{array}{c}\text { Volume } \\
\left(\mathrm{m}^{3}\right)\end{array}$ \\
\hline 2013 & 95 & $1,444,584$ & 89 & $1,346,740$ & 84 & $1,272,408$ & 80 & $1,236,137$ \\
\hline 2007 & 225 & $3,644,280$ & 219 & $3,501,000$ & 214 & $3,390,385$ & 208 & $3,307,195$ \\
\hline
\end{tabular}

However, there are discrepancies between the reported and simulated inundation areas, especially in the lower part of the Manggarai gate point. This is because the inundated water from the upstream is flowing down to the lower part of the Manggarai gate area. In the real situation in Jakarta, there are river banks and which makes it difficult for the inundated water to across the river banks and flow down to the downstream area. This is the reason for the discrepancy for the lower part of the Manggarai gate point of the Ciliwung River. Thus, in addition to the improvement of the spatial distribution of the rainfall by using the radar data, those inundation behaviors should be taken into account in the model simulation to get a better simulation result: The local manning's $n$ value or the land elevation value needs to be changed to reflect the local effect of those river banks and/or artificial structures. It is also noted that there are pumping stations in the northern coastal area in Jakarta for dewatering, but those artificial structures and activities were not taken into account in the flood inundation simulation of this paper.

It can be seen from Figure 3 that the maximum inundation depth of more than $1.0 \mathrm{~m}$ can be found near the Manggarai gate point. As already mentioned in the previous chapter, these inundated lower sections of the Ciliwung River are likely to cause the shortage of capacity flow because of the narrow river cross sections. The computation of the 2013 flood and the observation results show this inundation situation at these sections in the Ciliwung River. As such, these sections are vulnerable against high flood flows from the upstream.

In the next chapter, a counter measure to increase the flood carrying capacity in these sections will be evaluated based on the calibrated flood inundation model discussed.

\section{INCREASE OF FLOOD CAPACITY}

In this chapter the effects of a counter measure on reducing the flood extent and volume in Jakarta are quantitatively evaluated by the flood inundation model. The counter measure discussed in this paper is to increase the flood flow capacity in the lower Ciliwung River which has narrow cross sections. As explained earlier, there are areas with a small flood flow carrying capacity in the upstream sections of the Manggarai gate, shown in Figure 1 and these areas are always inundated during the flood events. In this chapter, the flood flow capacity in those sections is evaluated to find if it is increased by expanding the river width in the flood inundation simulation.

The target flood events are the 2007 and 2013 floods. In addition to the 2013 event, the 2007 event was simulated using the same parameters calibrated for the 2013 event and included for the analysis in order to check the effects under the different scales.

The flood flow capacity in the narrow sections of $14.8 \mathrm{~km}$ zone from the Manggarai gate in the Ciliwung River was increased under the 3 simulation cases; Case 1: $50 \%$, Case 2: $100 \%$ and Case 3: $150 \%$. The flood flow capacity was found to be increased by widening the river width. In other words, the flow areas of the river were expanded in the flood simulation.

Figure 4 shows the differences of the inundation depth before and after the counter measures for Case 1 and Case 3 of the events. As indicated in the figures a decrease of both the inundation depth and area (minus values in the figure) can be found with the increase of the flood flow capacity of the river.

It should be emphasized that, in general, the enlargement of the narrow sections might increase the flood risk in the downstream area, so that this kind of counter measures should be carefully checked by numerical simulations before implementation. In the case of this paper, there are enough flood carrying capacities in the West Canal and the downstream of the Ciliwung River, so that the increase of the flood inundation depth and area after the countermeasure was not observed.

The simulation results are summarized in Table 2 . Under the Case 3, the flood area reduced from $95 \mathrm{~km}^{2}$ to $80 \mathrm{~km}^{2}$ in the 2013 event and from $225 \mathrm{~km}^{2}$ to 208 $\mathrm{km}^{2}$ in the 2007 event. In the flood inundation volume case, about $15 \%$ of decrease can be read in the 2013 event under the Case 3. Accordingly, it can be said that the counter measure to increase the flood flow carrying capacity in the narrow sections of the Ciliwung River is a useful option to reduce the flood extent and damages in Jakarta.

It should be noted that there are illegally constructed houses in the upstream sections of the Manggarai gate (Kure et al. ${ }^{4}$ ), so that the increase of the flood flow capacity of the river is not easy task to implement. Also, it should be emphasized that there are many areas still remaining flooded because the factors contributing to the flooding in Jakarta are not only by the Ciliwung 
River but also by other rivers flowing into Jakarta.

In this paper, one counter measure was discussed but there are many other options such as 1) dredging in the river, 2) constructing diversion tunnels to the East and West Canals, 3) increasing the number and capabilities of the pumping stations in the lower area, 4) constructing the infiltration wells in the upper regions, 5) increasing the capacity of both natural and artificial ponds or lakes (Situ) in the upper regions, etc. Those options should also be quantitatively evaluated by the numerical model associated with a cost-benefit analysis in order to mitigate flood damages in Jakarta.

\section{CONCLUSIONS}

In this paper several problems causing flooding in Jakarta were discussed and a flood inundation model was applied to the 2007 and 2013 flood events. Also, the effects of the counter measure to increase the flood flow carrying capacity of the Ciliwung River on the flooding were evaluated by the numerical simulation.

As a result of analysis, it was found that the applied flood inundation model relatively well reproduced the flood inundation situation in Jakarta but the model needs to be improved by using the radar data and taking account of artificial structures in the flood inundation zone to get a better simulation result. The counter measure that increased the flood flow capacity of the target sections by $150 \%$ was found to reduce the flood inundation volume by about $15 \%$ in Jakarta. However, considering the fact that many areas of the city still inundated, it would also be necessary to investigate the effects of other rivers and many other factors causing flooding.

It should be noted that the cross section datasets employed in this paper have some uncertainties because of lack of information. Those cross section data should be updated through local surveys. It should also be noted that artificial structures such as river banks, gates and pumping stations in the floodplains were not taken into account in the model simulation in the paper. Therefore, the results presented in the paper should be considered as initial assessment results.

ACKNOWLEDGMENT: This research was supported by the Environment Research and Technology Development Fund (S-14) of the Ministry of the Environment, Japan. We are grateful to the member of JICA-BNPB and JICA-PW for their kind supports during our on-site survey. The 2013 flood inundation map and data used in this paper were provided by the BPBD. The authors would like to thank Ms. Atsuko Hashimoto for her insightful comments and review of the paper.

\section{REFERENCES}

1) Farid, M., Mano, A., and Udo, K.: Modeling Flood Runoff Response to Land Cover Change with Rainfall Spatial Distribution in Urbanized Catchment. Annual Journal of Hydraulic Engineering, Vol. 55, pp.19-24, 2011.

2) Kure, S. and Tebakari T.: Hydrological Impact of regional climate change in the Chao Phraya River Basin, Thailand, Hydrol. Res. Lett., Vol.6, pp.53-58, 2012.

3) Bricker J. D., Tsubaki R., Muhari A., and Kure S.: Causes of the January 2013 Canal embankment Failure and Urban Flood in Jakarta, Indonesia, Journal of Japan Society of Civil Engineers, Ser. B1 (Hydraulic Engineering), Vol.70, No.4 pp. I_91-I_96, 2014.

4) Kure S., Farid M., Fukutani Y., Muhari A., Bricker J.D., Udo K., and Mano A.: Several Social Factors Contributing to Floods and Characteristics of the January 2013 Flood in Jakarta, Indonesia, Journal of Japan Society of Civil Engineers, Ser. G, Vo. 70, No.5, pp.I_211-I_217, 2014. (in Japanese with English abstract).

5) ATLAS:SAFETY BEACH JAKARTA (Draft), pp.123, 2011, Available at : http://ja.scribd.com/doc/72755643/ATLAS-JakartaCoastal-Defense-Strategy

6) Kure, S. and Yamada, T.: Nonlinearity of runoff and estimation of effective rainfall in a slope. Proceedings of the $2^{\text {nd }}$ Asia Pacific Association of Hydrology and Water Resources Conference, Vol.2, pp.76-85, 2004.

7) Kure, S., Watanabe, A., Akabane, Y., and Yamada, T.: Field Observations of Discharge and Runoff Characteristics in Urban Catchments Area. Proceedings of $11^{\text {th }}$ International Conference on Urban Drainage, United Kingdom, pp.1-10, 2008.

8) Kure. S., Jang, S., Ohara, N., Kavvas, M.L., and Chen, Z.Q.: WEHY-HCM for Modeling Interactive AtmosphericHydrologic Processes at Watershed Scale: II. Model Application to Ungauged and Sparsely-gauged Watersheds, Journal of Hydrologic Engineering, Vol.18, No.10, pp.1272-1281, 2013.

9) Carpenter, T.M., Sperfslage, J.A., Georgakakos, K.P., Sweeney, T., and Fread, D.L.: National threshold runoff estimation utilizing GIS in support of operational flash flood warning systems, Journal of Hydrology, Vol.224, pp.21-44, 1999.

10) DHI: MIKE 21 FLOW MODEL: Hydrodynamic Module Scientific Documentation, 2009.

11) European Space Agency: Climate Change Initiative Land Cover Products, 2013, Available at: http://www.esa-landcover-cci.org/ 